\title{
Charcoal rot severity and yield components of common bean cultivars inoculated with Macrophomina phaseolina
}

\author{
Eduardo José Zanella1 ${ }^{1}$, Juliano Berghetti ${ }^{1} \oplus$, Bruno Tabarelli Scheidt ${ }^{1} \oplus$, Ricardo Trezzi Casa ${ }^{1}$, Amauri Bogo ${ }^{1}$, \\ Mayra Juline Gonçalves ${ }^{1} \mathbb{0}$, Flávio Chupel Martins ${ }^{1}[0$
}

${ }^{1}$ Programa de Pós-Graduação em Produção Vegetal, Universidade do Estado de Santa Catarina, Avenida Luiz de Camões, 2090, CEP 88520-000, Lages, Santa Catarina, Brasil.

Corresponding Author: Juliano Berghetti (julianoberghetti@yahoo.com.br)

Data de chegada: 09/07/2020. Aceito para publicação em: 08/09/2020.

$10.1590 / 0100-5405 / 240745$

\section{ABSTRACT}

Zanella, E.J.; Berghetti, J.; Scheidt, B.T.; Casa, R.T.; Bogo, A.; Gonçalves, M.J.; Martins, F.C. Charcoal rot severity and yield components of common bean cultivars inoculated with Macrophomina phaseolina. Summa Phytopathologica, v.46, n.4, p.299-304, 2020.

Macrophomina phaseolina is a soilborne pathogen with a wide range of hosts and its control through agricultural practices is difficult. The aim of this study was to quantify the severity of root rot (SRR) caused by M. phaseolina in common bean cultivars and its impact on yield components. The experiments were carried out under greenhouse conditions with the common bean cultivars 'ANFC-9 Agro Norte', 'BRS Esteio', 'BRS Estilo', 'BRS Pérola', 'FTS Soberano', 'IPR Campos Gerais', 'IPR Tangará', 'IPR Tuiuiú', 'IPR Uirapurú' and 'TAA Dama'. Three isolates of M. phaseolina obtained from infected plants of common bean, soybeans and maize were inoculated in the common bean cultivars. In the phenological stage R9 of grain harvest maturity, the SRR and the yield components of root dry mass (RDM), number of pods per plant
(NPP), number of grains per plant (NGP) and grain mass per plant (GMP) were assessed. All common bean cultivars were susceptible to M. phaseolina, showing a reduction in NPP, NGP and GMP. SPR was greater than $75 \%$, regardless of the origin of isolates. Considering the average of cultivars, there was a significant decrease of $54.3 \%$ in RDM, compared to control treatments. The cultivars 'IPR Tangará', 'ANFC-9 Agro Norte', 'BRS Esteio', 'BRS Pérola' and 'FTS Soberano' had a decrease in at least one yield component, while a reduction occurred in all components for cultivar 'IPR Tangará'. There was an average decrease in NPP, NGP and GMP of 7.9\%, 7.6\% and 7.2\%; 13.4\%, $12.8 \%$ and $6.7 \%$; and $14.2 \%, 12.9 \%$ and $10.1 \%$, considering the isolates obtained from beans, soybeans and maize, respectively.

Keywords: Phaseolus vulgaris, genetic resistance, soilborne fungi.

\section{RESUMO}

Zanella, E.J.; Berghetti, J.; Scheidt, B.T.; Casa, R.T.; Bogo, A.; Gonçalves, M.J.; Martins, F.C. Severidade da podridão de carvão e componentes de produção de cultivares de feijão comum inoculadas com Macrophomina phaseolina. Summa Phytopathologica, v.46, n.4, p.299-304, 2020.

Macrophomina phaseolina é um patógeno de solo com uma grande variedade de hospedeiros e de difícil controle por práticas culturais. O objetivo deste estudo foi quantificar a severidade da podridão das raízes (SPR) causada por M. phaseolina em cultivares de feijoeiro comum e seu impacto nos componentes de produção. Os experimentos foram conduzidos em casa de vegetação com as cultivares de feijão comum ANFC-9 Agro Norte, BRS Esteio, BRS Estilo, BRS Pérola, FTS Soberano, IPR Campos Gerais, IPR Tangará, IPR Tuiuiú, IPR Uirapurú e TAA Dama. Três isolados de M. phaseolina obtidos de plantas infectadas de feijão, soja e milho foram inoculados nas cultivares de feijão. No estádio fenológico R9 da maturidade da colheita de grãos foram avaliados o SPR e os componentes de produção de massa seca de raízes (MSR), número de legumes por planta (NLP), número de grãos por planta (NGP) e massa de grãos por planta (MGP). Todas as cultivares de feijão foram suscetíveis a $M$. phaseolina, apresentando redução no NLP, NGP e MGP. A SPR foi superior a $75 \%$, independentemente da origem dos isolados. Na média das cultivares houve decréscimo significativo de $54,3 \%$ na MSR quando comparadas aos tratamentos controle. As cultivares IPR Tangará, ANFC-9 Agro Norte, BRS Esteio, BRS Pérola e ‘FTS Soberano’ obtiveram redução em pelo menos um dos componentes da produção enquanto a cultivar IPR Tangará em todos. Observouse decréscimo médio de NLP, NGP e MGP de 7,9\%, 7,6\% e 7,2\%; $13,4 \%, 12,8 \%$ e $6,7 \%$; e $14,2 \%, 12,9 \%$ e $10,1 \%$, considerando os isolados obtidos de feijão, soja e milho, respectivamente.

Palavras-chave: Phaseolus vulgaris, resistência genética, fungos de solo.

Common beans are susceptible to different pathogens such as anthracnose (Colletotrichum lindemuthianum (Sacc. \& Magn.) Br. \& Cav.), white mold (Bary Sclerotinia sclerotiorum (lib.)), rust (Uromyces appendiculatus (Pers.) Unger.), angular leaf spot (Phaeoisariopsis griseola (Sacc.) Ferraris), and root rot complex (4). Among root rot are dry root rot (Fusarium solani (Mart.) Sacc), Fusarium wilt (F. oxysporum Schlecht), rhizoctoniosis (Rhizoctonia solani Kuhn) and charcoal rot (Macrophomina phaseolina (Tassi) Goid). The latter is considered one of the most prevalent pathogens in Brazil.

M. phaseolina is a cosmopolitan pathogen with a wide range of hosts and over 500 different species, including economic crops, such as bean (P. vulgaris L.), maize (Zea mays L.), soybean (Glycine max (L.) Merrill), sorghum (Sorghum bicolor (L.) Moench, peanut (Arachis hypogaea L.), sunflower (Helianthus annuus L.) and cotton (Gossypium hirsutum L.) (7, 11, 13, 18).

Roots and stems are the main parts affected by this pathogen, which can infect plants at any time of the growing season. Most infection may occur early in the season, but typical symptoms will only develop after flowering, when plants become stressed (3, 9, 11). M. phaseolina produce microsclerotia which can remain free in the 
soil as a major source of primary inoculum $(7,14,16)$. The favorable conditions for root infection are soil compaction and water restriction periods $(3,15)$.

Yield reductions of 5\% to $50 \%$ have been reported for the soybean crop, according to the environmental conditions and the genotype susceptibility $(13,16,27)$. The authors observed that bean plants artificially inoculated with $M$. phaseolina showed $60 \%$ grain yield decrease when compared to plants naturally grown in infested soils.

Agricultural practices such as crop rotation is unviable to reduce the incidence of M. phaseolina due to its wide range of hosts and inoculum survival in the soil $(3,22)$. Using a resistant cultivar is the major control strategy $(6,12,13,16)$. However, in Brazil, there are few studies of genotype resistance in beans.

The pathogen variability, as regards pathogenicity and aggressiveness, is critical since $M$. phaseolina has a wide range of host species, indicating that the fungus is heterogeneous in isolates. Moreover, attempts to classify fungal isolates into subgroups based on their morphology and pathogenicity are not consistent $(16,19)$.

The aim of this study was to quantify the severity of root rot (SRR) caused by M. phaseolina in common bean cultivars and its impact on yield components.

\section{MATERIAL AND METHODS}

Experiments were carried out during 2017 and 2018 at the laboratory and greenhouse of Santa Catarina State University, Lages Municipality, Santa Catarina State, Brazil.

Three M. phaseolina isolates, MEMR31, MEMR57 and MEMR89, were obtained from infected root tissue of 'BRS MG Madrepérola' bean, 'BMX Lança IPRO' soybean, and 'P1630H' maize hybrid, respectively. The inoculum of isolates was multiplied in potato-dextrose-agar (PDA) medium incubated in a Biochemical Oxygen Demand (BOD), at $28^{\circ} \mathrm{C}$, for 10 days. Pure $M$. phaseolina colonies were ground in a blender, following the ratio of 10 Petri dishes $(90 \mathrm{~mm})$ for each 500 $\mathrm{mL}$ distilled water plus one drop of Tween $20(0.1 \mathrm{~mL})$. The final inoculum concentration was adjusted on a hemocytometer to $3 \times 10^{4}$ $\mathrm{mL}^{-1}$ microsclerotia.

A 250-mL unfiltered inoculum suspension was sprayed with a hand sprayer into a $0.5-\mathrm{kg}$ substrate and sand mixture at the ratio of $2.3: 1$. The "final product" (substrate plus inoculum) was placed in 8-L plastic pots, homogenized and stored in a greenhouse for ten days until the sowing date. Water irrigation was performed every three days to improve fungal colonization on the substrate. N-P-K chemical fertilization was added to the substrate according to the Soil Analysis and Fertility Commission for the states of Rio Grande do Sul and Santa Catarina, based on the expected yield of 4,000 kg ha' (5).

Ten common bean genotypes were assessed: 'ANFC 9 Agro Norte', 'BRS Esteio', 'BRS Estilo', 'BRS Pérola', 'FTS Soberano', 'IPR Campos Gerais', 'IPR Tangará', 'IPR Tuiuiú', 'IPR Uirapurú' and 'TAA Dama'. Six seeds were sown per pot, and thinning was conducted three days after seedling emergence, keeping two final plants per pot. Experimental design was completely randomized with four replicates and each pot as an experimental unit. Controlled irrigations were performed to maintain the normal growth and development of plants, aiming at grain production.

Yield components were assessed in phenological stage R9 (grain harvest maturity), as follows: i) number of pods per plant (NPP), by counting and manually removing pods from all plants; ii) number of grains per plant (NGP), by manual trailing, separation and counting of grains; iii) grain mass per plant (GMP), by drying the grains in an air circulation oven at $60^{\circ} \mathrm{C}$ until constant weight was obtained in an analytical scale; iv) severity of root rot (SRR), and v) root dry mass (RDM) (10). To assess SRR and RDM, all plants were removed from the pots and their root system was carefully washed in running water to remove the substrate. The roots were dipped in white-bottomed trays containing water for visualization and quantification of SRR, according to an adaptation of the diagrammatic scale (1), as follows: 1) Absence of symptoms, healthy plant, $0 \%$ severity; 2) Slight root discoloration, lesions limited to $10 \%$ tissue; 3) $25 \%$ root tissue showing lesions, decreased number and volume of secondary roots; 4) $50 \%$ root tissue showing lesions, visible microsclerotia, and 5) 75\% root tissue showing lesions, root system with minimal roots. The qualitative rate of the diagrammatic scale was adapted by adding equidistant intervals of $25 \%$ severity, where: 1) 0 to $25 \%$ severity; 2) $25 \%$ to $50 \%$ severity; 3) $50 \%$ to $75 \%$ severity, and 4) $75 \%$ to $100 \%$ severity. The root system was cut, separated from the aerial part, kept in paper bags and dried in an air circulation oven until constant weight was reached in subsequent weighing for obtaining the RDM data.

Data were studied by analysis of variance (ANOVA) in a factorial scheme, according to $F$ test $(\mathrm{p}<0.05)$, using the SISVAR 5.6 program (8). Treatments were subjected to means test $(\mathrm{p}<0.05)$ with Scott-Knott and Tukey's test for the cultivar and isolate factors, respectively.

\section{RESULTS AND DISCUSSION}

All common bean cultivars were susceptible to M. phaseolina, showing different levels of severity of root rot (SRR) and a reduction in most yield components such as number of pods per plant (NPP), number of grains per plant (NGP) and grain mass per plant (GMP), regardless of the origin of bean, soybean or maize isolates.

The variation factor (I) of $M$. phaseolina isolates was statistically significant for the yield components NPP and root dry mass (RDM). However, NPP and GMP did not show significant differences among isolates (Table 1). NGP was significant lower when the common bean cultivars were inoculated with the M. phaseolina isolates MEMR31 from bean (56.1) and MEMR57 from soybean (56.5), compared to plants inoculated with the isolate MEMR89 from maize (60.4) (Table 2).

Table 1. Analysis of variance for the yield parameters: number of pods per plant (NPP), number of grains per plant (NGP), grain mass per plant (GMP) and root dry mass (RDM) evaluated in common bean cultivars inoculated with different isolates of Macrophomina phaseolina. Lages/ SC, Brazil.

\begin{tabular}{ccccc}
\hline $\begin{array}{c}\text { Variation } \\
\text { Factor }\end{array}$ & NPP & NGP & GMP & RDM \\
\hline Isolates (I) & $0.02^{\text {ns }}$ & $3.40^{*}$ & $0.93^{\text {ns }}$ & $61.15^{*}$ \\
Cultivars (C) & $4.94^{*}$ & $9.96^{*}$ & $8.73^{*}$ & $25.71^{*}$ \\
I x C & $0.89^{\text {ns }}$ & $2.54^{*}$ & $2.08^{*}$ & $6.25^{*}$ \\
\hline CV (\%) & 14.17 & 14.21 & 15.39 & 19.58 \\
\hline
\end{tabular}

*Significant at $5 \%$ probability of error; ${ }^{\text {ns }}$ not significant.

The yield component that showed the greatest decrease was $\mathrm{RDM}$, regardless of the origin of the isolate. The plants produced, on average, $1.31 \mathrm{~g}$ less RDM, compared to the control plot, showing a reduction of 54.3\%. MEMR31 and MEMR57 from bean and soybean, 
respectively, were the most aggressive isolates and did not show any statistical difference. Plants inoculated with MEMR31 and MEMR57 produced, on average, $0.95 \mathrm{~g}$ RDM and were statistically different from plants inoculated with MEMR89 from maize, which produced $1.41 \mathrm{~g}$ RDM (Table 2).

The origin of M. phaseolina isolates tested in this study was tropical and subtropical regions of Brazil and, according to Muñoz-Cabañas et al. (19), isolates from these regions showed greater aggressiveness to common bean cultivars, when compared to isolates from arid regions of Mexico. Almeida et al. (2), Prabhu et al. (21), Sánches et al. (23), Sarkar and Mandal (24) and Sexton et al. (25) reported that M. phaseolina isolates from the same or different hosts had significant genetic variability, which can explain the differences found in this study between MEMR31 (bean) and MEMR57 (soybean), when compared to MEMR89 (maize). MEMR31 and MEMR57 did not show any significant difference in aggressiveness and led to the most reduced RDM, compared to MEMR89, which suggests that isolates from the same botanical family (Fabaceae) present similar aggressiveness.

There was no significant difference between the yield components
NPP and GMP regarding the isolate variation factor (I). The effect of the three isolates on NPP and GMP was a reduction of $7.6 \%$ and $12.4 \%$, respectively, when compared to the control plot (Table 2). All yield components showed significant differences regarding the cultivar variation factor $(\mathrm{C})$. Thus, the yield features of each common bean cultivar were taken into account, although $M$. phaseolina infection affected the yield components at different intensity degrees.

There was no significant difference among isolates when NPP was assessed. However, the cultivars 'ANFC-9 Agro Norte', 'BRS Estilo', 'BRS Pérola', 'IPR Campos Gerais', 'IPR Tuiuiú' and 'IPR Uirapurú' showed higher NPP when compared to 'BRS Esteio', 'FTS Soberano', 'IPR Tangará' and 'TAA Dama'. 'IPR Tangará' was the only cultivar that was significantly influenced by $M$. phaseolina isolates, presenting a reduction of $24.6 \%$ in NPP when compared to the control plot (Table 3 ).

The common bean cultivars showed a significant difference for the yield parameter NGP; inoculated plants produced $11 \%$ less NPG when compared to the control plot. The most productive and significantly different non-inoculated cultivars were 'BRS Esteio' (81.7 grains/ plant $^{-1}$ ) and 'IPR Uirapurú' (79.1 grains/plant $\left.{ }^{-1}\right)$. 'BRS Esteio' showed

Table 2. Number of pods per plant (NPP), number of grains per plant (NGP), grain mass per plant (GMP) and root dry mass (RDM) of common bean cultivars inoculated with isolates of Macrophomina phaseolina from different hosts. Lages/SC, Brazil.

\begin{tabular}{|c|c|c|c|c|}
\hline Isolate & $\begin{array}{c}\text { NPP } \\
\left(\text { pods.plant }^{-1}\right)\end{array}$ & $\begin{array}{c}\text { NGP } \\
\left.\text { (grains.plant }^{-1}\right)\end{array}$ & $\begin{array}{c}\text { GMP } \\
\left.\text { (g.plant }^{-1}\right)\end{array}$ & $\begin{array}{c}\text { RDM } \\
\left(\text { g.root }^{-1}\right)\end{array}$ \\
\hline MEMR31(bean) & $14.11 \mathrm{~B}$ & $56.14 \mathrm{C}$ & $13.40 \mathrm{~B}$ & $0.94 \mathrm{C}$ \\
\hline MEMR57(soybean) & $14.16 \mathrm{~B}$ & $56.50 \mathrm{C}$ & $13.59 \mathrm{~B}$ & $0.95 \mathrm{C}$ \\
\hline MEMR89 (maize) & $14.22 \mathrm{~B}$ & $60.45 \mathrm{~B}$ & $14.03 \mathrm{~B}$ & $1.41 \mathrm{~B}$ \\
\hline Control & $15.32 \mathrm{~A}$ & $64.82 \mathrm{~A}$ & $15.61 \mathrm{~A}$ & $2.41 \mathrm{~A}$ \\
\hline Reduction $(\%)^{2}$ & 7.6 & 11.0 & 12.4 & 54.4 \\
\hline
\end{tabular}

${ }^{1}$ Overall average of the three isolates; ${ }^{2}$ Reduction: 100 - [(Average ${ }^{1} /$ Control) $\left.* 100\right]$; Means followed by different capital letters in the column differ statistically from each other according to Scott-Knott test $(\mathrm{p}<0.05)$.

Table 3. Number of pods per plant (NPP) and number of grains per plant (NGP) of common bean cultivars inoculated (I) or not (NI) with Macrophomina phaseolina isolates. Lages/SC, Brazil.

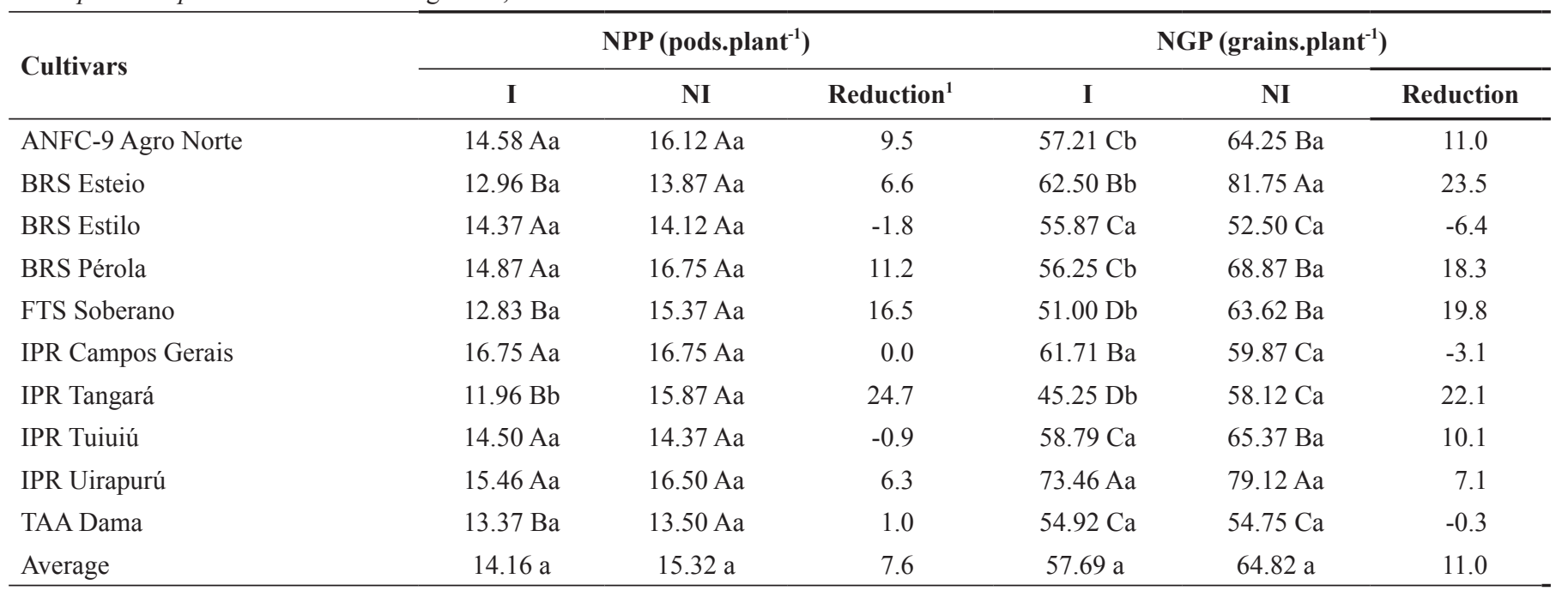

${ }^{1}$ Reduction (\%): 100-[(I/NI) *100]; Means followed by different uppercase letters in the column and lowercase letters on the row differ statistically from each other according to Scott-Knott test $(\mathrm{p}<0.05)$. 
a decrease of $23.5 \%$ in NGP, the highest percentage, compared to the control plot (Table 3).

Inoculated plants had, on average, a reduction of $12.4 \%$ in GMP, when compared to the control plot. 'FTS Soberano' showed the lowest GMP, 10.21 g.plant ${ }^{-1}$, but produced 12.36 g. plant $^{-1}$ when not inoculated and did not differ from 'IPR Tuiuiú', 13.39 g.plant ${ }^{-1}$, and 'TAA Dama', 14.79 g.plant ${ }^{-1}$. All cultivars presented a decrease in GMP, which ranged from $1.8 \%$ to $24.2 \%$. 'IPR Tangará' had a reduction of $24.2 \%$ and was considered the most susceptible cultivar considering GMP (Table 4). In general, plants inoculated with $M$. phaseolina, regardless of the origin of the isolate, showed a decrease of $54.3 \%$ in RDM, ranging from $34.0 \%$ to $70.0 \%$. The cultivars 'BRS Esteio' and 'IPR Uirapurú' showed the greatest and smallest reduction in RDM, 70.0\% and 34.0\%, respectively (Table 4).

Plants inoculated with isolates of $M$. phaseolina manifested symptoms of longitudinal black lesions in the root tissue and stem, producing dark mycelium and microsclerotia. In addition, the infected roots were apparently smaller and without secondary roots. The observed symptoms corroborate the data obtained by Méndez-Aguilar et al. (17). There was a significant difference in the plant growth rate among all common bean cultivars, evidencing distinct behaviors regarding flowering, leaf senescence and plant death. In general, plants inoculated with $M$. phaseolina showed premature leaf fall and early maturation, resulting in early plant death. There was a reduction in the development cycle for all cultivars, ranging from three to 23 days. Compared to the control, the cultivar that most hastened its development cycle due to infection by the pathogen was 'TAA Dama' (Figure 1). This behavior is not atypical and was already observed for infected soybean plants $(20,26)$. Plants inoculated with $M$. phaseolina isolates showed, on average, a 13-day cycle reduction, when compared to the control plot.

NGP was significant for the interaction between isolate (I) and cultivar (C). There was no significant difference between the isolates MEMR31 and MEMR57; however, they significantly differed from
MEMR89. Cultivars inoculated with MEMR89 produced, on average, 4.31 and 3.95 more grains than cultivars inoculated with MEMR31 and MEMR57, representing $7.1 \%$ and $6.5 \%$ of their production, respectively. The general behavior of cultivars in relation to isolates was similar. However, the most susceptible cultivar to MEMR31 was 'BRS Esteio', which also had different behaviors towards the other two isolates (MEMR57 and MEMR89). MEMR89 from maize was the least aggressive isolate to all common bean cultivars (Table 5).

There was an interaction between isolate (I) and cultivar (C) factors for the yield component RDM. The isolates MEMR31 and MEMR57 were more aggressive in reducing RDM, significantly differing from MEMR89. Cultivars inoculated with MEMR89 produced a 0.47 higher RDM than cultivars inoculated with MEMR31 and MEMR57. The isolate MEMR89 was least aggressive to the cultivars 'BRS Pérola', 'FTS Soberano', 'IPR Tangará', 'IPR Tuiuiú' and 'TAA Dama'. In addition, MEMR31 was most aggressive to 'BRS Esteio' and 'IPR Uirapurú' (Table 5).

All cultivars were highly susceptible to $M$. phaseolina isolates because the epidemiological parameter SRR showed no statistical variance among factors/treatments. The SRR level was superior to $75 \%$ for all factors/treatments, indicating high disease intensity (Table 6). The results of SRR evaluation evidence the efficiency of the methodology adopted in this study and can be helpful for further experiments and bioassays with the objective of assessing bean germplasm banks or genotypes to M. phaseolina.

The SRR above $75 \%$ obtained in this study can be explained by the inoculation condition. The favorable environmental conditions and the inoculation methodology in a greenhouse, compared to field conditions, were responsible for the higher disease severity found for the common bean cultivars. Experiments conducted under greenhouse conditions tend to offer favorable conditions for the pathogen development and the genetic expression of genotypes, since these conditions are not easily applicable in the field, leading to discrepancy between results obtained

Table 4. Grain mass per plant (GMP) and root dry mass (RDM) of common bean cultivars inoculated (I) or not (NI) with Macrophomina phaseolina isolates. Lages/SC, Brazil.

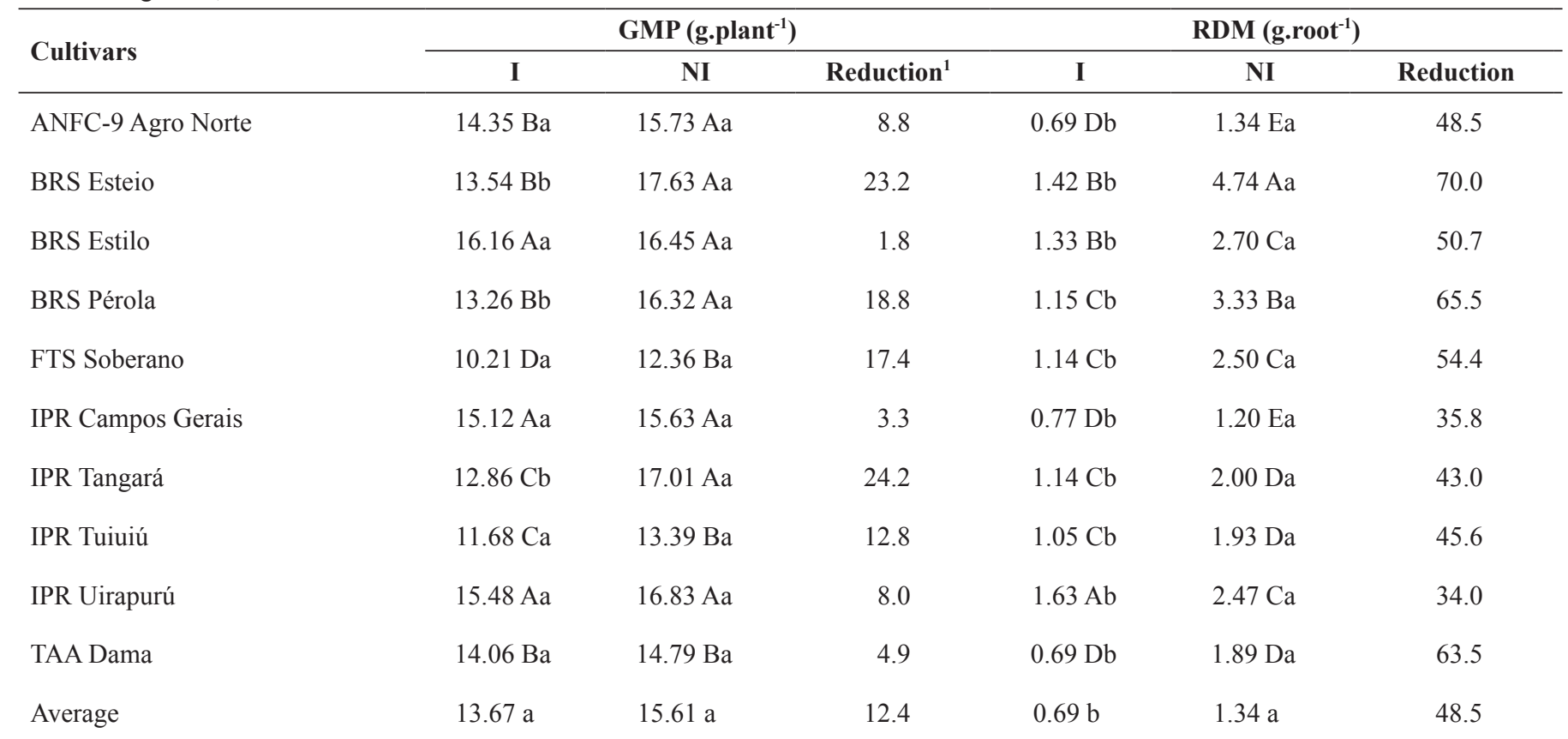

${ }^{1}$ Reduction (\%): 100-[(I/NI) 100]; Means followed by different uppercase letters in the column and lowercase letters on the row differ statistically from each other according to Scott-Knott test $(\mathrm{p}<0.05)$. 


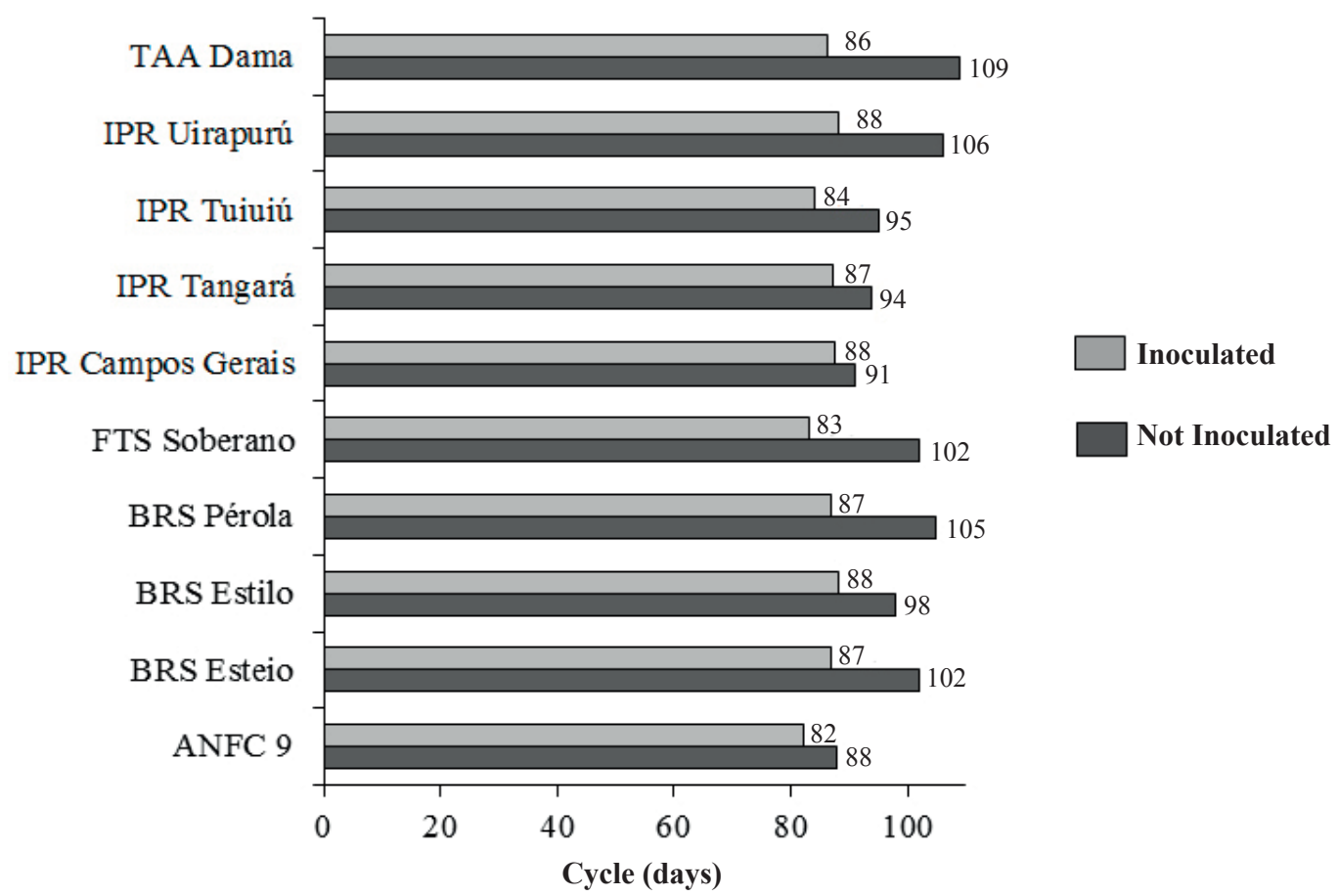

Figure 1. Average developmental cycle of common bean cultivars in relation to plants inoculated or not with Macrophomina phaseolina isolate. Lages/SC, Brazil.

Table 5. Split analysis of variance for number of grains per plant (NGP: grains.plant ${ }^{-1}$ ) of common bean cultivars related to Macrophomina phaseolina isolates and cultivars. Lages/SC, Brazil.

\begin{tabular}{|c|c|c|c|}
\hline \multirow{2}{*}{ Cultivars } & \multicolumn{3}{|c|}{ Isolates } \\
\hline & MEMR31 & MEMR57 & MEMR89 \\
\hline ANFC-9 Agro Norte & $60.12 \mathrm{Aa}^{*}$ & $50.37 \mathrm{Ba}$ & $61.12 \mathrm{Ca}$ \\
\hline BRS Estilo & $54.62 \mathrm{Aa}$ & $54.50 \mathrm{Ba}$ & $58.50 \mathrm{Ca}$ \\
\hline BRS Pérola & $59.25 \mathrm{Aa}$ & $56.37 \mathrm{Ba}$ & $53.12 \mathrm{Ca}$ \\
\hline IPR Tangará & $40.12 \mathrm{Ba}$ & $50.75 \mathrm{Ba}$ & $44.87 \mathrm{Da}$ \\
\hline IPR Tuiuiú & $56.62 \mathrm{Aa}$ & $54.25 \mathrm{Ba}$ & $65.50 \mathrm{Ba}$ \\
\hline IPR Uirapurú & $71.75 \mathrm{Aa}$ & $73.12 \mathrm{Aa}$ & $75.50 \mathrm{Aa}$ \\
\hline TAA Dama & $57.50 \mathrm{Aa}$ & $51.12 \mathrm{Ba}$ & $56.12 \mathrm{Ca}$ \\
\hline BRS Estilo & $1.28 \mathrm{Aa}$ & $1.31 \mathrm{Ba}$ & $1.40 \mathrm{Ba}$ \\
\hline BRS Pérola & $0.80 \mathrm{Bb}$ & $0.62 \mathrm{Db}$ & $2.01 \mathrm{Aa}$ \\
\hline FTS Soberano & $1.10 \mathrm{Ab}$ & $0.72 \mathrm{Dc}$ & $1.61 \mathrm{Ba}$ \\
\hline IPR Campos Gerais & $0.72 \mathrm{Ba}$ & $0.62 \mathrm{Da}$ & $0.95 \mathrm{Ca}$ \\
\hline IPR Tangará & $0.68 \mathrm{Bc}$ & $1.14 \mathrm{Bb}$ & $1.61 \mathrm{Ba}$ \\
\hline IPR Tuiuiú & $0.90 \mathrm{Bb}$ & $0.94 \mathrm{Cb}$ & $1.31 \mathrm{Ba}$ \\
\hline IPR Uirapurú & $1.32 \mathrm{Ab}$ & $1.72 \mathrm{Aa}$ & $1.86 \mathrm{Aa}$ \\
\hline TAA Dama & $0.63 \mathrm{Bb}$ & $0.40 \mathrm{Db}$ & $1.04 \mathrm{Ca}$ \\
\hline Average & $0.94 \mathrm{~b}$ & $0.95 \mathrm{~b}$ & $1.41 \mathrm{a}$ \\
\hline
\end{tabular}

*Means followed by different uppercase letters in the column and lowercase letters on the row differ statistically from each other according to Scott-Knott test ( $\mathrm{p}<0.05$ ). 
Table 6. Severity of root rot caused by Macrophomina phaseolina in common bean cultivars. Lages/SC, Brazil.

\begin{tabular}{ccc}
\hline Cultivars & Severity (\%) & Reaction \\
\hline ANFC-9 Agro Norte & $75-100$ & Susceptible \\
BRS Esteio & $75-100$ & Susceptible \\
BRS Estilo & $75-100$ & Susceptible \\
BRS Pérola & $75-100$ & Susceptible \\
FTS Soberano & $75-100$ & Susceptible \\
IPR Campos Gerais & $75-100$ & Susceptible \\
IPR Tangará & $75-100$ & Susceptible \\
IPR Tuiuiú & $75-100$ & Susceptible \\
IPR Uirapurú & $75-100$ & Susceptible \\
TAA Dama & $75-100$ & Susceptible
\end{tabular}

under these two environmental conditions.

All assessed common bean cultivars are susceptible to $M$. phaseolina, showing a reduction in NPP, NGP and GMP and different SRR level, regardless of the origin of isolates.

\section{REFERENCES}

1. Abawi, G.S.; Pastor-Corrales, M.A. Root rots of beans in Latin America and Africa: diagnosis, research methodologies, and management strategies. Ed 35, Cali: CIAT, 1990, 114p.

2. Almeida, A.M.R.; Abdelnoor, R.V.; Arias, C.A.A.; Carvalho, V.P.; Jacoud Filho, D.S.; Marin, S.R.R.; Benato, L.C.; Pinto, M.C.; Carvalho, C.G.P. Genotypic diversity among brazilian isolates of Macrophomina phaseolina revealed by RAPD. Fitopatologia Brasileira, Brasília, v.28, n.3, p.279$285,2003$.

3. Almeida, A.M.R. Macrophomina phaseolina em soja. Londrina: Embrapa Soja, 2014, 55p

4. Campos, A.A.B.; Scotton, J.C.; Costa, W.L.F.; Giassi, V.; Pinto, D.F.P.; Homma, S.K. Seleção de fungicidas visando à preservação de fungos micorrízicos arbusculares nativos no cultivo do feijoeiro. Revista Brasileira de Engenharia Agrícola e Ambiental, Campina Grande, v.19, n.9, p.898-902, 2015.

5. Comissão De Química e Fertilidade Do Solo. CQFS - RS/SC. Manual de calagem e adubação para os Estados do Rio Grande do Sul e Santa Catarina. 11 Ed. Porto Alegre, 2016. 376p.

6. Cruciol, G.C.D.; Costa, M.L.N. Influência de metodologias de inoculação de Macrophomina phaseolina no desempenho de cultivares de soja. Summa Phytopathologica, Botucatu, v.43, n.4, p.32-37, 2018.

7. Dhingra, O.D.; Sinclair, J.B. Biology and pathology of Macrophomina phaseolina. Imprensa Universitária: Viçosa, Minas Gerais, 1978. 166p.

8. Ferreira, D.F. Sisvar: a computer statistical analysis system. Ciência e Agrotecnologia, Lavras, v.35, n.6, p.1039-1042, 2011.

9. Garcés-Fiallos, F.R. Cuantificación de enfermidades em líneas promisoras y variedades de fréjol en Quevedo, Ecuador. Biotecnología em el setor agropecuário y agroindustrial, Popayán, v.11, n.1, p.196-207, 2013.

10. Gepts, P.; Fernándes, F. Etapas de desarrollo de la planta de frijol comum (Phaseolus vulgaris L.). Cali: CIAT, 1982, 10p.

11. Gupta, G.K.; Sharma, S.K.; Ramteke, R. Biology, epidemiology and management of the pathogenic fungus Macrophomina phaseolina (Tassi) Goid with special reference to charcoal rot of soybean (Glycine max (L.) Merrill). Journal of Phythopathology, Blackwell Verlag, v.160, n.4, p.167-180, 2012.

12. Gutiérrez, J.C.; Ramírez, J.S.P.; Salinas, E.L.; Pérez, N.M. Effect of Macrophomina phaseolina (Tassi) Goid. on grain yield of common beans (Phaseolus vulgaris L.) and its relationship with yield stability parameters. Revista Mexicana de Fitopatologia, Texcoco, v.21, n.2, p.168-175, 2003.

13. Ishikawa, M.S.; Ribeiro, N.R.; Oliveira, E.C.; Almeida, A.A.; Balbi-Peña, M.I. Seleção de cultivares de soja para resistência à podridão negra da raiz (Macrophomina phaseolina). Summa Phytopathologica, Botucatu, v.44, n.1, p.38-44, 2018.

14. Maringoni, A.C.; Lauretti, R.L.B. Reação de genótipos de feijoeiro comum a Fusarium oxysporum f. sp. phaseoli, Macrophomina phaseolina e Xanthomonas campestris pv. phaseoli. Pesquisa Agropecuária Brasileira, Brasília, v.34, n.4, p.535-542, 1999.

15. Martínez-Villarreal, R.; Garza-Romero, T.S.; Moreno-Medina, V.R.; Herł nández-Delgado, S.; Mayek-Pérez, N. Bases bioquímicas de la tolerancia al estrés osmótico em hongos fitopatógenos: el caso de Macrophomina phaseolina (Tassi) Goid. Revista Argentina de Microbiología, Ciudad Autónoma de Buenos Aires, v.48, n.4, p.347-357, 2016.

16. Mayék-Pérez, N.; López-Castañeda, C.; López-Salinas, E.; Cumpián-Gutiérrez, J. Resistencia a Macrophomina phaseolina (Tassi) Goid. en frijol común en condiciones de campo en México. Agrociencia, Montecillo, v.35, n.6, p.649-661, 2001.

17. Méndez-Aguilar, R.; Reyes-Valdes, M.H.; Mayek-Pérez, N. Avances y perspectivas sobre el mapeo genético de la resistencia a las pudriciones de la raíz en frijol común. Phyton International Journal of Experimental Botany, Vicente López, v.82, n.2, p.215-226, 2013.

18. Mengistu A.; Arelli, P.; Bond, J.; Nelson, R.; Rupe, J.; Shannon, G.; Wrather, A. Identification of soybean accessions resistant to Macrophomina phaseolina by field screening and laboratory validation. Plant Health Progress, v.10, n.1, 2013.

19. Muñoz-Cabañas, R.M.; Hernández-Delgado, S.; Mayek-Pérez, N. Análisis patogénico y genético de Macrophomina phaseoliona (Tassi) Goid. en diferentes hospedantes. Revista Mexicana de Fitopatologia, Texcoco, México, v.23, n.1, p.11-18, 2005.

20. Pearson, C.A.S.; Schwenk, F.W.; Crowe, F.J.; Kelley, K. Colonization of soybean roots by Macrophomina phaseolina. Plant Disease, Saint Paul, v.68, p.1086-1088, 1984.

21. Prabhu, H.V.; Adiver, S.S.; Bhat, R.S.; Narayana, Y.D. Genetic variability in Macrophomina phaseolina (Tassi.) Goid., causal agent of charcoal rot of sorghum. Karnataka Journal of Agricultural Sciences, v.25, n.1, p.72-76, 2012.

22. Reis, E.M.; Segalin, M.; Moraes, N.L.; Ghissi, V.C. Efeitos da rotação de culturas na incidência de podridões radiciais e na produtividade da soja. Summa Phytopathologica, Botucatu, v.40, n.1, p.09-15, 2014.

23. Sánchez, S.; Chamorro, M.; Henríquez, J.L.; Grez, J.; Díaz, I.; Santos, B.; Gambardella, M. Genetic and biological characterization of Macrophomina phaseolina (Tassi) Goid. causing crown and root rot of strawberry. Chilean Journal of Agricultural Research, Chillián, v.77, n.4, p.325-331, 2017.

24. Sarkar, S.K.; Mandal, D. Variability of Macrophomina phaseolina (Tassi) Goid in major jute growing areas of India. Journal of Micopathological Research, Kolkata, v.53, n.2, p.283-285, 2015.

25. Sexton, Z.F.; Hughesb, T.J.; Wisea, K.A. Analysing isolate variability of Macrophomina phaseolina from a regional perspective. Crop Protection, v.81, p.9-13, 2016.

26. Short, G.E.; Wyllie, T.D.; Ammon, V.D. Quantitative enumeration of Macrophomina phaseolina in soybean tissues. Phytopathology, v.68, p.736-741, 1978.

27. Yang, X.B.; Navi, S.S. First report of charcoal rot epidemics caused by Macrophomina phaseolina in soybean in Iowa. Plant Disease, Saint Paul, v.89, n.5, p.526, 2005. 